\title{
Mbalax - Música Popular no Senegal: Uma tradição moderna entre herança colonial e World Music
}

\author{
Katharina Döring ${ }^{1}$
}

Resumo: O presente artigo descreve aspectos da música popular da África ocidental, focando no gênero música Mbalax do Senegal que surgiu a partir dos anos 60/70, e que continua vivo até hoje na região com vários subgêneros. Tal gênero musical foi protagonizado entre outros pelo cantor e compositor senegalês Youssou N' Dour, que propagou esse movimento internacionalmente. Procura-se ampliar a visão sobre a música popular e tradicional africana no cenário acadêmico brasileiro, comparando alguns aspectos e posições sobre as fronteiras flutuantes entre o que seria música tradicional e música popular.

Palavras-chave: Mbalax, música popular africana, Senegal, World Music

Abstract: The present article describes some aspects of popular music occidental Africa, focusing on the Mbalax from Senegal, which appeared by decades 60 and 70, headed among others by famous singer and composer Youssou n'Dour, who made this movement known worldwide, that continues alive since today in that region, with a lot of ramifications. It seeks to broaden the vision and knowledge about popular and traditional African music in the Brazilian academic landscape comparing some aspects about the fluid front lines between what is supposed to be traditional or popular music.

Keywords: Mbalax, african popular music, Senegal, World Music

\section{Música popular africana - que música - que tempo - que África?}

As políticas afirmativas para a população afro-brasileira, a implantação da Lei 10.639 sobre a obrigatoriedade do ensino da história e cultura africana, indígena e afro-brasileira, assim como pesquisas interdisciplinares nas últimas décadas sobre músicas e culturas afro-brasileiras, contribuíram para a valorização e preservação das raízes africanas no Brasil, principalmente através de programas e editais do então Ministério de Cultura (Fundação Cultural Palmares, IPHAN), voltados para populações quilombolas, expressões contemporâneas e tradições culturais dos povos afrodescendentes. Através do programa do patrimônio imaterial e várias medidas de políticas afirmativas, tradições musicais e rituais cênicos de matrizes africanas, como o samba de roda, jongo, tambor de crioula, carimbo, coco, congadas, batuque de umbigada etc., foram estudados e divulgados pelo Brasil inteiro.

1Professora Doutora da Universidade do Estado da Bahia. E-mail: Katharina.doring@gmail.com. 
A busca pelas origens negras na cultura brasileira, também contribuiu com o interesse pelas raízes estéticas e musicais no continente africano, que, para os movimentos culturais e políticos negros no Brasil, ainda se configura como matriz, fonte, origem, na expressão saudosa: 'Mãe África'. Ao conhecer melhor alguns países africanos, viajantes, pesquisadores e produtores culturais se surpreenderam com essa 'Mãe' África, que por um lado folclorizou um imaginário estereotipado das Áfricas tribais e que por outro lado parece ter parentesco com um subúrbio brasileiro, em revelar uma mistura de ritmos urbanos, eletrônicos e hiper-produzidos, ecoando pelos milhares de becos das periferias pobres e populosas. Entre imagens bucólicas de homens e mulheres em batas coloridas dançando e cantando ao som de tambores, xilofones e kalimbas, e no outro extremo, as sonosferas alucinantes das cenas musicais contemporâneas, torna se urgente, conhecer a história, presença e mercado dos inúmeros gêneros da música popular africana, que continuam esbanjando uma criatividade ímpar, embasados nos pilares de uma vasta produção fonográfica de várias décadas.

A diversidade cultural e musical dos países e grupos étnicos e culturais africanos, tanto nas suas tradições orais, locais e regionais, como nas músicas populares urbanas e transnacionais, é muito pouco conhecida e documentada no Brasil. Na mídia, se veicula a imagem de uma África, como se fosse um país único com cultura genérica, de predominância rural, tribal, com rituais e religiões, supostamente 'primitivos', e uma música exclusivamente percussiva: o binômio: Africano = Tambor se estabelece como equação comparável a Alemão = Bach/Beethoven! Muitos pesquisadores africanos buscam modificar essa visão simplificada, descrevendo detalhadamente as diferenças, mas também a união na diversidade musical:

Foi demonstrado, que existe uma grande diversidade de estilos musicais na África, que se revelam nos seus materiais tonais, que são utilizados nas culturas singulares como formas de expressão. (...). Estas formas mais variadas, no entanto, se fundamentam em princípios estruturantes em comum, exemplificados pelo emprego de melodia e ritmo, na relação com a polifonia ou no uso dos mais variados recursos musicais. (...) a história demonstra que nunca existiram culturas musicais isoladas, mas que elas sempre estiveram em contato e influencia mutua. (NKETIA, 1987, p. 42)

O mais importante dessa unidade na diversidade das expressões, é a compreensão da expressão musical como uma expressão do coletivo, do diálogo, da atividade coletiva e social e não necessariamente enquanto atitude individualista que favorece a visão de "arte", "consumo" e “celebridade". Neste sentido, torna se compreensível, a importância e função dos tambores na 
maioria dos países africanos, com sua diversidade incrível, quanto a sonoridades, timbres, tamanhos, construção, material, forma, maneira de tocar. Os tambores exercem um papel fundamental nas músicas sacras e populares das respectivas culturas, porém contam com a presença de milhares de instrumentos percussivos e melódicos desconhecidos, que compõem a riqueza da música africana tradicional, assim como das músicas populares que tomou vários rumos, sendo influenciado por estilos e gêneros musicais populares do mundo inteiro.

No presente artigo, não será possível, oferecer uma introdução e visão geral sobre os principais gêneros musicais em alguns países africanos, porque o tema poderia facilmente preencher vários tomos. O foco aqui é dado para a música popular do Senegal, especificamente o abrangente e ramificado gênero Mbalax, porque o Senegal oferece na sua cultura e história musical uma vasta gama de tradições musicais, ao lado de músicas populares contemporâneas, devido a influências múltiplas da diáspora africana entre outros. Seu ritmo popular Mbalax figura entre as músicas populares mais versáteis do continente africano e se cristalizou a partir da segunda metade do séc. XX na cena da música popular de Dakar, gerando uma plataforma para a projeção no cenário da World Music, de grandes estrelas musicais como Youssou N'Dour e Baaba Maal entre muitos outros.

\section{Tradições musicais no complexo cultural Senegâmbia}

Senegal é um país pequeno situado na Costa do Oeste da África entre Mauritânia e GuineaBissau que revela uma diversidade e riqueza musical ímpar, devido a suas inúmeras etnias e tradições diferentes. Os povos e línguas mais conhecidos são os Wolof, Pulaar e Serer, além da presença importante dos Fulani ou Tukulor no norte do país e os Mandinka/Mandingos: os descendentes dos Mande de Mali no sul do país e principalmente em Gâmbia. Em quase todo continente africano, as manifestações musicais acompanham os demais estágios da vida, assim como o cotidiano e trabalho na vida rural. No Senegal, as tradições musicais, chamadas de Cosaan são marcadas por narrativas vocais e estilos melódicos, que evidenciam influencias muçulmanas, assim como pela polirritmia, que se revela na complexidade e excelência rítmica, apresentada por uma grande variedade de conjuntos instrumentais. Segundo o New Groves a habilidade instrumental dos músicos é impressionante, como também seu canto com variações sutis de timbre e o controle de legato e vibrato. O uso de várias escalas, algumas pentatônicas, a maioria heptatônicas, revelam a flexibilidade (melismática) do canto, dando uma inflexão da voz para cima ou para baixo, que não 'ataca' as notas musicais precisamente. 
Senegal e Gâmbia (complexo cultural Senegambia) dividem a mesma tradição Griô como Mali e Guinea, na qual a música está nas mãos de uma classe hereditária de cantores de louvor, chamados Gewel em Wolof e Gawlo em Pulaar. Esta tradição é uma herança dos Mandingo de Mali, onde são chamados de Jáli, os quais formaram um império nos séculos XIV até XVI, com extensão até Senegambia. No séc. XIX, o Senegal recebeu um novo fluxo de migração de Jális Mandingos do Mali para o Senegal que influenciaram a cultura musical e poética do pais. Muitos griôs em Senegambia se referem aos seus ancestrais Mande e trouxeram consigo vários instrumentos característicos da tradição Mande, a Kora (harpa-alaúde com 21 cordas e uma cabaça grande como corpo de ressonância), o Balafon (xilofone grande com cabaças de ressonância por baixo de cada tecla de madeira), e ainda o Xalam ou Khalam, um alaúde da tradição Wolof com cinco cordas que seria uma adaptação do Ngoni dos Mande. A música dos griôs, no entanto, não está limitada aos próprios Mandingos, porque foi se divulgando entre as etnias Wolof, Pulaar e Serer, que por sua vez contribuíram com a transformação dessas tradições musicais. A influência musical dos Serer, por exemplo, se manifesta pela polifonia vocal e o canto litúrgico das irmandades muçulmanas que estão presentes há vários séculos em algumas regiões do Senegal.

Seguindo a tradição oral dos griôs, os quais antigamente como músicos profissionais cantaram e tocaram para os nobres, e hoje em dia cada vez mais para políticos e empresários em rituais e festas familiares, os senegaleses apreciam a música no seu uso funcional e nos rituais tradicionais, tendo comportamentos diversos de acordo com sua classe social:

Em sociedades com estratificação social, como entre os Haussa em Nigéria e os Wolof em Senegambia, o fazer musical pertence a uma classe socialmente inferior e a participação ativa somente se encontra nesse nível. A classe superior se satisfez em ser entretido, e entrega a participação musical nos eventos culturais e cerimonias aos músicos profissionais... (NKETIA, em STOCKMANN, 1987, p. 19)

Os griôs, que falam várias línguas e dispõem de muitos conhecimentos e segredos históricos e culturais e de grande musicalidade e criatividade, antigamente tão apreciados, sofreram muitos preconceitos nos tempos coloniais. No entanto, muitos griôs exercem hoje profissões na administração e muitos músicos modernos não são mais de famílias tradicionais de griôs. A islamização do país contribuiu para uma atitude pejorativa da população em relação aos griôs, porque os líderes e sábios da tradição griô representariam as religiões 'animistas' e músicas mundanas e sensuais, condenadas pelos muçulmanos. Apesar do declínio dessa herança e da 
influência crescente da música popular urbana, as tradições musicais diversas continuam forte nas várias regiões e etnias do Senegal e influenciam por sua vez a música urbana e a criação de muitos estilos musicais contemporâneos. A partir do surgimento do Mbalax como unidade estruturante da música popular senegalesa, a exclusividade e excelência musical dos griôs começa a diminuir, porque cada vez mais, surgem músicos amadores e profissionais das mais diversas origens étnicas e sociais que, no entanto, reconhecem a sua competência musical:

Unanimidade predomina entre meus interlocutores sobre um tópico: os Griôs e seus descendentes conheceriam melhor a música tradicional com seus ritmos diversos, seus gêneros, seus padrões para o arranjo da voz, acompanhamento instrumental e percussão. Nesse campo eles são imbatíveis e continuam assim por muito tempo. Deve ser por isso, que em muitas bandas, tem pelo menos um integrante, descendente de família Griô. (PANZACCHI, 1997, p. 83)

Nas demais culturas musicais locais e regionais, muitas tradições são perpetuadas, mas passam por ressignificações e mudanças socioculturais, devido à urbanização, conflitos de gênero, religião e geração, estratificação socioeconômica, entre muitos outros, o que não é diferente nas sociedades africanas. A família tradicional griô está se transformando, abrindo espaço para novas configurações, criações, e missões estéticas e socioculturais.

\section{Surgimento das cenas musicais populares na África ocidental}

A cena musical urbana no Senegal demorou a desenvolver sua própria música popular que viria a ser o Mbalax. Isso aconteceu a partir dos anos 70. Em outros países como principalmente Ghana e Nigeria, a chamada música Highlife que inicialmente misturou música africana tradicional dançante com shanties, hinos cristãos e música européia, se divulgou rapidamente e abriu caminho para inúmeros estilos e criações em regiões e épocas diferentes. Uma das bandas mais famosas foram os Tempo de E. T. Mensah de Ghana que acrescentaram elementos do Swing, Calypso e percussão afro-cubana ao Highlife e que durante sua longa turnê em 1958 acabou influenciando a música popular de vários países africanos.

A música popular Jújú dos Yorubá que combina música das bandas de violões e guitarras com estilos folclóricos neo-tradicionais, se torna famosa na Nigéria enquanto no Kongo se cristalizam estilos musicais populares baseados na música afro-cubana, principalmente na Rumba e em elementos jazzísticos. Nos países de colonização inglesa, a liberdade musical pareceu ser muito maior e deu espaço para muitas criações entre influências européias, afro-latinas, americanas (Jazz, 
Blues, Reggae) e tradições africanas, enquanto os países francófonos foram marcados por uma política de assimilação, sendo que a cultura francesa foi imposta às culturas nativas. O músico E. T. Mensah comenta suas experiências durante as viagens nos anos 60:

Os franceses dominam os negros na sociedade, o que tem seu efeito na música porque os brancos fazem tudo. Eles deixam trabalhar músicos brancos de Paris, enquanto os africanos (os músicos das orquestras) não estavam atualizados; portanto tinha pouca música dançante dos africanos. Quanto a aspectos sociais e musicais, o desenvolvimento nas regiões franceses começou somente a partir da independência e agora eles querem recuperar o tempo. (COLLINS, 1977, p. 24)

No Senegal, as coisas começaram a tomar novo rumo a partir do ano 60, quando o pais conquistou sua independência da Franca e muitas celebrações ocorreram, levando à formação de bandas musicais que se profissionalizaram como bandas permanentes nos clubes urbanos. Uma das precursoras foi a banda Star Band sob a liderança de Ibra Kasse que pode ser considerado como a primeira banda do estilo Mbalax, embora não plenamente desenvolvido, porque tocaram basicamente repertórios musicais afro-cubanos. É importante lembrar que não era de bom tom nas classes mais altas, ouvir música genuína africana e sim, música afro-cubana e afro-americana, principalmente depois da 2. Guerra Mundial, devido ao fato de que a partir dos anos 30, foram distribuídos no Senegal muitos LPs da música afro-cubana pelas majors da indústria fonográfica. $\mathrm{O}$ mais importante meio de divulgação das músicas afro-populares internacionais, eram as rádios que alcançaram quase toda população senegalesa. Começaram com a Rádio Dakar em 1939, pela administração francesa, que foi se transformando em Rádio Mali (1959) e Rádio Senegal (1960), cada vez mais veiculando músicas nacionais, e uma grande diversidade de músicas internacionais que influenciaram o gosto dos senegaleses. Assim se introduziu o jazz e, principalmente, a música afro-cubana

[...] desde da segunda guerra mundial, se toca e escuta Jazz no Senegal; no entanto, o círculo dos amantes do Jazz nunca foi muito grande; A importância maior na música senegalesa, tal qual a conhecemos hoje, foi a influência da mùsica afrocubana e latina. Rumba, Samba, Cha-cha-chá e Mambo, os estilos mais conhecidos, foram muito tocados e ouvidos; o mais querido, no entanto, foram Biguine, Morna, Pachanga e Merengue. (PANZACCHI, 1997, p. 41)

Os ritmos afro-latinos que se desenvolveram em vários gêneros musicais na diáspora 
africana no Brasil, Cuba, Jamaica, Colômbia, Cabo Verde etc., acrescentando elementos e instrumentos de origem europeias e indígenas, foram facilmente absorvidos pelos senegaleses que se encantaram com as semelhanças rítmicas e sonoras e as levaram para o próximo nível. A sua recepção no Senegal foi maior do que a música dançante moderna da Nigéria e de Ghana: o Highlife e o Juju, ambos também difundidas pelas rádios e pela venda de fitas cassetes.

A indústria fonográfica demorou a se instalar nos países africanos e sua produção durante décadas era voltada para as fitas cassetes, acessíveis em todos os mercados, camelôs, nas feiras e esquinas populares. O primeiro LP a ser gravado e imprensado em solo africano foi o álbum Amabutho do grupo sul-africano Ladysmith Black Mambazo na África do Sul, no ano de 1973 pela Gallo Records. A cena musical da África do Sul, conhecida internacionalmente pelos protagonistas Miriam Makeba, Ladysmith Black Mambazo e os coros tradicionais Isicathamiya, tinha conquistado um modesto mercado internacional e chegou a gravar muitos LPs no Estados Unidos e na Inglaterra, até abrir a produção própria na África do Sul. Diferente do sucesso internacional da música popular sul-africana (em plena apartheid), a música popular senegalesa levou muito tempo antes de ser conhecida fora da sua região, e seu reconhecimento começa pela classe média branca e não pelas comunidades da diáspora negra:

Curiosamente, a diáspora africana ainda precisa ser conquista pelo Mbalax. Os americanos de descendência africana, até recentemente não faziam parte da audiência de núcleo dos músicos senegaleses. Os primeiros que frequentaram os concertos de Youssou N'Dour nos Estados Unidos, foram imigrantes senegaleses e brancos. A maior comunidade de fãs do Mbalax fora do Senegal, consiste de pessoas sem ascendência africana. (PANZACCHI, 1997, p. 122)

Compreender o fenômeno histórico de que vários países africanos absorveram com muito entusiasmo as influências musicais afro-populares do "Novo Mundo", da diáspora africana, que encontraram seu caminho "de volta" para "Mãe África”, e que por outro lado, a diáspora africana na América Latina, no Brasil, no Caribe, nos Estados Unidos, muito pouco conhece, absorve, escuta e tematiza a música africana na sua vasta gama de tradições, ritmos, estilos, grupos e artistas incríveis, requer estudos mais aprofundados, mas primeiro o conhecimento específico sobre tais músicas que este artigo busca exemplificar com o Mbalax. 


\section{Mbalax: ritmos e instrumentos}

O estilo Mbalax foi surgindo, se modificando e se firmando aos poucos como um estilo musical complexo, marcado por um ritmo de acompanhamento, combinando elementos e influências rítmicas diversos. Segundo o African Music Enciclopedia on line o Mbalax é um ritmo percussivo do Senegal que foi modernizado por Youssou N'Dour e se caracteriza por uma combinação doce e "funky" de ritmos afro-cubanos, ritmos de tambores dos Wolof e "Pop" americano. Youssou N'Dour não foi o único a desenvolver o Mbalax, no entanto, com sua banda Super Etoile de Dakar aventurou inovações e novos experimentos na música popular, buscando combinações entre elementos tradicionais e recursos elétricos. Ele comenta sobre o surgimento do Mbalax: "Na minha banda dei algumas partes do tradicional Sabar para a guitarra, outras para o teclado, enquanto a guitarra rítmica assumiu o papel do tambor Mbung mbung“ (BROUGHTON, 1999:621)

O Sabar é o tambor principal de um conjunto de três tambores usado entre os Mandingo e Wolof, e geralmente usado para acompanhamento de dança. Todos os três são tocados com a mão esquerda e uma pequena baqueta na mão direita para complementar o ritmo. Sabar, além do nome do instrumento, significa uma festa dançante tradicional que acontece para mulheres de uma idade específica, para as mulheres jovens ao ar livre, ou para as mulheres mais velhas, num quintal ou outro espaço fechado. Os Sabars, que antigamente eram festas e eventos tradicionais na zona rural, acontecem também na vida metropolitana. Na música tradicional, uma formação típica Sabar consistia em 12 tambores, a depender do ocasião e lugar onde estavam tocando. O tambor que lidera o conjunto de tambores Sabar é chamado de Nder e dispõe de uma gama maior de notas musicais. Tem um tambor Sabar médio que é chamado de Mbung mbung, um nome onomatopeico que ilustra bem a sonoridade flexível e ressonante deste tambor. O ritmo do Mbung mbung (som grave, papel do baixo) em combinação com o Sabar (som agudo), o Gorong-yegé (som agudo para solos) e o Ndeund (tambor maior) forneceu a base de uma parte instrumental que se chama justamente Mbalax, dando o nome ao ritmo Mbalax. Mais tarde iria assumir sua característica definitiva com a idéia de transpor ritmos tradicionais para instrumentos elétricos, acrescentado ainda pelos timbres sonoros de outros instrumentos tradicionais como o Xalam e o Tama, que é o tambor falante com um papel fundamental no Mbalax. Obviamente um ritmo com uma longa trajetória, já se ramificou em vários estilos e passou por interpretações e transformações diversas, tanto que existem fusões como rock-mbalax e rap-mbalax. O jornalista musical John Cho explica os elementos do Mbalax da seguinte maneira: 
Música popular cubana se enraizou no Senegal, mas o híbrido que brotou no seu solo desértico "osso duro de roer", estava muito longe das eufonias aveludadas do Congo. As progressões harmônicas latinas "melodramáticas" e as interjeições recortadas dos sopros sobreviveram, enquanto os registros vocais agudos e melismaticos dos muezins islâmicos com seus acompanhamentos árabes e modais foram introduzidos, o que resultou numa mistura harmônica estimulante. A riqueza dos padrões percussivos tradicionais dos Wolof, foi entrelaçada com os tambores sabars, djembes e tamas, tocados ao lado da bateria ocidental. Um diálogo "fogo rápido" entre o cantor e o tocador do tama, muitas vezes representa o ápice da canção. $\mathrm{O}$ som resultante começou a ser conhecido como mbalax, e sua estética subjacente é quente, rápida e complexa.

Quase todas as músicas desse novo gênero preservam o acompanhamento típico Mbalax que dá destaque principalmente ao tambor Mbung mbung e a solos dos outros tambores acima descritos. Ainda podem ter conjuntos de tambores com tambores graves que fazem acompanhamentos, chamados de Talmbat e Tulli, e como aquisição mais recente ao conjunto Sabar, configure o pequeno tambor Tungune, que significa literalmente duende.

$\mathrm{Na}$ verdade, poderia-se dizer que o Mbalax não seria um único gênero ou ritmo musical, e sim, muito mais um encontro explosivo dos cantos, ritmos e instrumentos musicais das tradições musicais do Senegal, com as influências musicais afro-latinas que acrescentam e transformam as harmonias da música europeia. Seria um estilo musical camaleônico em evolução perpétua, mas que apresenta uma unidade essencial que tem sido imediatamente reconhecida e absorvida pelos músicos populares no Senegal, marcando uma época de várias décadas e sua imortalidade no cenário das músicas populares africanas.

\section{História do Mbalax}

$\mathrm{Na}$ vida urbana de Senegal até nos anos 60 praticamente só existiam orquestras dançantes que, tocando exclusivamente para uma elite, mantinham um repertório europeu, a chamada "varieté française" como p. ex. a Lyre Africaine, orquestra da municipalidade de Dakar. Também existiram alguns grupos musicais mais voltados para o Jazz como o Saint-Louisien-Jazz e Amical Jazz de Saint Louis e outros. Em geral, os músicos talentosos receberam apoio do colonizador francês e estudaram no Conservatório de Música em Dakar, subentendendo-se que eles iriam seguir carreira de instrumentista na tradição europeia, o que contribuiu para a profissionalização e uma boa formação de muitos músicos, porém, cada vez mais afastando-os das raízes tradicionais e rurais 
africanos. A partir dos anos 60, começa o sucesso de Ibra Kasse e sua Star Band, que inicialmente toca covers de música latina, principalmente afro-cubanas. Mas como os senegaleses falavam Wolof, a língua do colonizador francês e ainda uma língua materna, eles não entenderam as letras em espanhol, e os imitaram, misturando com outras palavras familiares, assim popularizando os ritmos latinos.

Ao contrário do Congo, a música no Senegal não era uma atividade subversiva que punha em risco a existência colonial. Tal entendimento no Congo teve como resultado o fato de que a influência dos ritmos afro-cubanos na música popular congolesa chegou bem mais tarde do que em outros países africanos. O que marcou mais a realidade moderna em Dakar foi um processo de urbanização, profissionalização e individualização que contribuiu com maior independência dos músicos, buscando seus caminhos longe da ordem colonial, porém não baseados na música senegalesa tradicional, considerada para os músicos 'modernos' e 'civilizados', como algo vergonhoso e atrasado. Este quadro mudou com a independência em 1960 e a ideologia da Negritude concebida pelo escritor Leopold Senghor que foi presidente do país durante 20 anos e que conseguiu semear uma nova consciência que iniciou a busca cultural pelas raízes africanas. A dedicação de Senghor ao resgate da cultura tradicional do seu país, em pouco tempo marcou o Senegal como líder na literatura africana, no cinema e nas artes plásticas. O movimento da Negritude começou com Leopold Senghor e Aimé Césaire a partir dos anos 30, quando eles estudavam na França, lutando pelo orgulho e reconhecimento da cultura, literatura e arte africana, contrariando a colonização francesa. Quando, com Senghor, a independência finalmente foi conquista no ano 1960, as artes e culturas africanas foram destaque na sua presidência, assim como em outros países independentes que começaram a formar companhias de dança e música africanas, revelando a riqueza coreográfica e musical de suas inúmeras etnias e grupos culturais.

A música dos Griots também foi promovida como uma tradição clássica africana e foram estimulados conjuntos com instrumentos tradicionais, buscando e pesquisando os saberes por parte negligenciados. A música urbana deveria defender essas tradições e as línguas nacionais através de composições e adaptações apropriadas, segundo modelos de outros países africanos como o Zaire e a Guinea. Porém, a população urbana acostumada com seus estilos musicais populares dançantes que serviram em primeiro lugar, para se divertir, não aderiu diretamente ao projeto de africanização e o processo da criação de uma música popular genuinamente senegalesa que viria a ser o Mbalax com sua mistura de ritmos e timbres tradicionais, ritmos afro-cubanos, música popular do Kongo, e outros elementos, foi se desenvolvendo aos poucos nos anos 60/70 e se firmando nos anos 80 . 
A Star Band de Ibra Kasse foi uma das primeiras orquestras dançantes a passar por um processo de africanização, porém, mantendo sua linha baseada nos ritmos afro-cubanos e caribenhos, tão apreciados no Senegal durante décadas. Eles começaram a substituir o espanhol (muitas vezes fantasioso) do repertório afro-cubano pelas línguas Wolof e Mandingo, e o tambor Tama foi introduzido com ritmos tradicionais e sua linguagem e sonoridade características. As danças que imitaram os estilos jazzísticos deram espaço para elementos africanos, como o famoso "ventilador", acirrado pelo acompanhamento frenético do Tama.

A Star Band teve três sucessores importantes, fundada por seus ex-membros: Number One $d u$ Senegal com seu famoso vocalista Pape Seck e que continuou a reforçar cada vez mais as raízes africanas; Orchestre Baobab que está atuando até hoje e deu mais ênfase no estilo afro-cubano, porém desenvolvendo uma linguagem própria; e principalmente o Étoile de Dakar, fundado em 1977, que começou a liderar a música popular durante vários anos e firmar definitivamente o Mbalax como a marca da música popular no Senegal. A música do Étoile de Dakar apresentou uma mistura maravilhosa de cantos grios, sopros fulminantes e ritmos pulsantes e uma atitude refrescante que mudou a comportamento da nova geração. O jovem Youssou N'Dour começou sua ascensão como estrela musical com Etoile de Dakar e se tornaria em pouco tempo um símbolo para seu país. Em 1979, quando os membros do Étoile buscaram caminhos diferentes, N'Dour formou a banda dele: Super Étoile de Dakar e não parou mais de produzir sucessos tanto no mercado nacional como internacional.

Outras bandas importantes no cenário da música popular senegalesa têm ou tiveram um papel importante, trazendo sobretudo influências do Jazz, do Funk e do Rock, experimentando fusões com o Mbalax como o Xalam que foi fundado em 1970: ainda no ano 1988, lançaram um CD misturando Jazzfunk com canto e percussão dos Griots. Uma banda muito apreciada pela juventude urbana no Senegal foi Omar Pene e os Super Diamono, principalmente pela sua atitude e militância política inspirada no reggae, denunciando corrupção, desemprego, violência etc. e misturando funk, rock, jazz e a percussão do Sabar de uma maneira particular que foi pioneiro no desenvolvimento do Mbalax. Nos últimos anos o movimento musical dos jovens urbanos, é principalmente dominado pelo Rap que passou por uma fase de imitação do Rap americano e se consolidou com um estilo próprio, cujo exponente mais conhecido é a banda Positive Black Soul que realizou shows junto com outros artistas musicais como Ismail Lô, Osmar Pene etc. Em Dakar existem atualmente cerca de 2000 bandas de Rap! Não é possível dar espaço para todos os artistas e estilos musicais, quero apresentar somente um pouco da trajetória de dois músicos famosos, tanto 
no meio musical nacional como internacional para comentar sua inserção no fenômeno World Music.

\section{Youssou N'Dour e Baaba Maal}

N'Dour nasceu ca. 1959 em Medina como filho de um Serer e uma Tukulor e foi criado na tradição dos Grios e como membro de uma irmandade do Mouridisme, uma forma popular do Islã no Senegal, que se baseiam na filosofia dos Sufi que tem como referencial admirado seu fundador Cheikh Ahmadou Bamba. Desde sua infância Youssou N'Dour foi considerado um fenômeno com sua voz abençoada e participou como cantor no ritual do Kassak que acontece no final da iniciação masculina. Contra a vontade do seu pai, Youssou começou a cantar profissionalmente na Star Band com 16 anos de idade e logo depois, com 18 anos se tornou um dos membros fundadores do famoso Étoile da Dakar. Em 1979, ele formou a própria banda Super Étoile de Dakar na qual ele também atuou como produtor, iniciando uma nova fase para os músicos senegaleses que se tornariam mais independentes, construindo o mercado popular nacional, sendo que até hoje por boa parte dele, é controlado pelos Mourides.

Em poucos anos Youssou N'Dour se tornou uma estrela nacional querida por todos, referencial para todos os senegaleses, cantando sobre os problemas e temas das pessoas comuns, seus prazeres, suas tradições, sobre suas famílias e principalmente exaltando a beleza e importância das mulheres e das mães. Nos anos 80, encontrando o desafio de uma nova geração de músicos sofisticados e politicamente conscientes como os Super Diamono, N'Dour começou a tratar mais de temáticas sociais, como migração econômica, importância da identidade africana, a apartheid entre outros.

\footnotetext{
"Música na África jamais pode ser separada de vida cotidiana", disse N'Dour. "Suas funções sociais e morais são um dado para todos os africanos. Minhas músicas geralmente são canções-mensagens de algum jeito ou de outro, mesmo as músicas de amor têm a tendência de transmitir mensagens na roupagem de canções românticas" (ROOTSWORLD, 19.11.2000)
}

Youssou N'Dour consolidou o estilo Mbalax com sua banda em âmbito nacional e internacional, sempre buscando inovações. Eles começaram a experimentar com ritmos cruzados e complicados do conjunto dos tambores Sabar no qual os tambores afinados travam uma sucessão de diálogos com mudanças rápidas em tempo e ritmo, para criar novas estruturas inusitados. N'Dour teve vários sucessos internacionais e se tornou famoso em parcerias com Peter Gabriel, Neneh 
Cherry, Sting entre outros, mas continuou lançando regularmente as acessíveis fitas cassete para o mercado local. Ele se destacou também como produtor cultural, fomentando a cena local, gravando outros músicos no seu estúdio Jololi, como p.ex. a música "Ne la Thiass" de Cheikh Lô que se tornou um sucesso internacional. Youssou N'Dour, apesar do seu sucesso internacional, continua com uma presença forte no Senegal, onde reside e toca toda semana até de madrugada no seu clube "Thiossane" para ficar em contato próximo com seu povo que reafirma suas raízes. Para compreender a dimensão desse artista internacional que se destaca também como ativista político e social e que é ainda pouco conhecido e apreciado no Brasil, alguns dados ajudam:

1 No ano 1985, ele organizou um concerto para o movimento Free Nelson Mandela!

2 Ele trabalhou com as Nações Unidas e a UNICEF, dando início ao projeto Joko que abriu cafés de internet no Senegal e outros países africanos

3 A revista Folk Roots reconheceu N'Dour como artista africano do século XX, tendo uma carreira internacional de turnês e álbuns por 40 anos.

4 Youssou é proprietário de um jornal importante l'Observateur no Senegal, assim como a estação de Rádio RFM e do canal de TV TFM.

5 Ele recebeu o reconhecimento como doutor honoris causa em música pela Yale University nos Estados Unidos, no ano 2011

6 No ano 2013, ele ganhou o prêmio Polar em música da Suécia por promover compreensão e tolerância entre as religiões e pela sua qualidade musical.

Essa lista poderia prosseguir ainda por muitos itens, tanto pela grande produção musical incrível de inúmeros fonogramas, turnês e shows da melhor qualidade e criatividade, como pela atuação como defensor de direitos humanos e da cultura africana, que até chegou a se candidatar como presidente, não pela ambição pelo poder, mas pelo dever ao seu povo.

Outro músico carismático e venerado no Senegal, é Baaba Maal que nasceu na região do norte do Senegal numa família nobre do povo nômade Fula que praticam um Islã, dito ‘puro’ desde o século XII e falam Pulaar, a língua materna na qual Baaba Maal canta a maioria das suas músicas. Embora não sendo de uma família de griots, ele começou a aprender música, cantando e tocando a kora de 12 cordas desde de menino e se inscreveu depois no conservatório de música em Dakar. Durante 10 anos, Maal tocou na banda Asly Fouta que utilizou somente instrumentos africanos e pesquisou a origem destes instrumentos, até que ele ganhou uma bolsa para a Escola de Belas Artes em Paris, onde estudou composição e arranjo. Quando voltou para o Senegal, começa a viajar com seu parceiro, o grio cego Mansour Seck pela África Ocidental, pesquisando o que sobrou da música tradicional. No ano 1985, Baaba Maal criou a banda Daande Lenol ("voz do povo"), com 
a qual aprimora seu estilo próprio utilizando a base do Mbalax para a combinação com estilos musicais tradicionais dos Pulaar, com músicas contemporâneas, sonoridades e timbres acústicos e eletrónicos. "Enquanto os demais músicos senegaleses que não são Wolof, (in) conscientemente se "wolofizaram" para "vender o seu peixe", Maal se enxerga como representante da cultura da sua comunidade linguística e é aceito e admirado pela mesma como tal. ” (PANZACCHI, 1997, p. 70)

$\mathrm{Na}$ sua longa trajetória como músico profissional há 20 anos, Maal alternou trabalhos acústicos com gravações de alto nível tecnológico e eletrónico, como nas suas performances, quando ele costumava revezar roupas sofisticadas de grife com batas preciosas da tradição africana. Numa entrevista com Nigel Williamson em 1999, Baaba Maal fala sobre suas primeiras impressões musicais inspiradas nos sons do dia-à-dia na sua aldeia no deserto, como p. ex. o marcante ritmo das mulheres moendo os grãos com pilões: "Eu escutava as melodias nesse som e as escutava no vento, nas árvores, no rio, em todo lugar, estava fascinado por todo tipo de som! ” (BROUGHTON, 1999 p. 626). Baaba Maal foi influenciado e pesquisou muitas músicas do complexo Atlântico Negro e continua aberto para suas inúmeras transformações e recriações na consciência das suas raízes musicais africanas. Ele fala de certos paralelos, como no caso da suposta influência do reggae no seu trabalho, que na verdade seria atribuída à música tradicional yela da sua região:

E uma imitação da sonoridade pilando os grãos. A estrutura é a mesma como no reggae. O ritmo entre a cabeça e o bater de palmas, é a mesma, como entre o bumbo e a guitarra na música jamaicana. (...). Eu estava convencido de que a música veio da África Ocidental. Então eu descobri o Jazz e o Blues. Essa música foi para América e voltou para nós. Se você vai para Dakar, tem agora muita música fantástica no estilo do rap africano. A linha do baixo é americana, mas continua sendo senegalês. Música africana viajou pelo mundo inteiro e agora voltou para casa. (MAAL em BROUGHTON, 1999, p. 627)

Baaba Maal continua morando na sua região em Podor onde ele mantém seu estúdio e toca freqüentemente em aldeias e regiões afastadas do povo Pulaar que o ama muito, além de construir e institucionalizar uma escola de artes, música e dança que está dando continuidade ao seu legado. Ele criou, consciente do papel e da importância para sua herança cultural, uma ponte entre o mundo global com suas tecnologias, filosofias e estilos de vida mais diversos, e a vida tradicional do seu povo nômade com sua vida religiosa e espiritual, baseado no Islã tradicional. Baaba Maal é um cantor, responsável para a transmissão da ética, moral e história da cultura africana, que demonstra isso com sua vida, se engajando em questões políticas e sociais, promovendo a formação musical e 
um festival de músicas africanas na sua região e desenvolvendo vários trabalhos e atividades através de uma fundação sociocultural.

\section{Contexto: Worldmusic}

O fenômeno Worldmusic não é novo no continente africano, porque as músicas populares africanas há décadas revelam uma grande criatividade em misturar diversos estilos e gêneros musicais, tanto tradicionais africanos, como europeus e as várias influências da diáspora afroamericana, afro-cubana, afro-brasileira etc. Existem vários argumentos contra o abuso e a exploração de músicas tradicionais, chamadas 'étnicas' do mundo inteiro, alegando a necessidade da preservação de valores, estéticas e sonoridades antigos e originais, como também a necessidade da proteção dos repertórios musicais frente a um mercado ocidental que engole todas as novidades para suprir os estoques da sua cultura esgotada.

Certamente deve se manter uma atitude crítica quanto à Worldmusic no seu aspecto meramente econômico, questionando imperialismo cultural, hegemonia econômica, perda de identidade e estética musical, mudança e apropriação de discursos entre outros aspectos. Porém não se deve subestimar a própria dinâmica e postura dos representantes e músicos da cena Worldmusic que não se encaixam de forma alguma na visão eurocêntrica sobre o que seria 'étnico', 'autêntico', 'tribal' e que buscam caminhos inusitados, combinando elementos novos e antigos de sua maneira, sem corresponder necessariamente à expectativa da audiência europeia ou americana.

O exemplo do Senegal, semelhante a outros países africanos e suas correntes e representantes da música popular, demonstra a grande variedade, dinâmica e autonomia das músicas populares africanas, no âmbito nacional e internacional. O problema consiste muito mais na visão etnocêntrica das culturas ocidentais que não percebem o grande movimento e desenvolvimento em outros complexos culturais, porque os veem como reservas, onde querem ir para se servir na superfície da riqueza musical africana, asiática ou latino-americana. O Brasil, embora seja um pais latino-americano, infelizmente tem reproduzido nas telecomunicações e em muitos contextos escolares e acadêmicos, essa visão eurocêntrica, como uma atitude (doença) crônica de se enxergar como um pais ocidental, que junto aos ex-colonizadores aprendeu esse olhar hierarquizado frente a outros países e contextos do eixo sul. Até mesmo na crítica ao modelo euro-americano, muitas vezes se reproduzem as atitudes, sem olhar de perto para os contextos específicos, neste caso as músicas populares de vários países africanos que tem muito que ensinar, inclusive aos brasileiros.

Questões como descaracterização, desapropriação, exploração e aproveitamento estético e 
econômico são discutidos internacionalmente desde os anos 90 em função da maior popularização de músicas tradicionais e populares, fora do mainstream da indústria fonográfica que começaram a ser divulgadas a partir dos anos 80. Esse fenômeno gerou um novo mercado musical, a chamada World Music, até hoje vivo em inúmeros festivais desse segmento no hemisfério norte, que apresentam uma miscelânea de estilos musicais de toda parte do mundo, mas seguem a lógica de mercado de entretenimento dentro de um espaço e nicho cultural bem definido. Com o esvaziamento dos gêneros pop/rock, vários artistas de renome internacional têm gravado com músicos de tradições populares africanos, latino-americanos e asiáticos. Tal atitude tem provocado o surgimento de controvérsias sobre usos e abusos dessas musicalidades originárias. Esse debate não obteve tanta repercussão no Brasil, até porque se trata de um país que dispõe de muitas "músicas do mundo", digamos, na própria casa. Poucos países como o Brasil possuem uma riqueza musical tão diversificada. São centenas de gêneros e estilos musicais e cênicos, urbanos, rurais, populares, (semi) eruditos, vocais, instrumentais, contemporâneos, tradicionais, (inter) nacionais, eletrônicos, acústicos quase sempre desconhecidos pela maioria dos brasileiros! Muito menos são conhecidos os milhares de gêneros musicais dos países africanos, muito mais festejados e valorizados na Europa do que na América Latina. As críticas ao processo de divulgação e popularização partem muitas vezes de pressupostos que não são necessariamente inerentes às culturas e comunidades tradicionais e sim ao mundo acadêmico e do consumo ocidental e suas classificações que enfatizam e constroem (mesmo nas entrelinhas) divisões teóricas:

1. Entre entretenimento e diversão, superficialidade por um lado e sagrado, religioso, ritual, seriedade;

2. Entre um espaço e tempo midiático artificial, construído externamente à comunidade e um espaço e tempo natural, orgânico, integrado à comunidade;

3. Entre o "comercial", interesses econômicos, barganha por poder, dinheiro e fama, induzido de fora pelo "capitalista" e o desinteressado, comunitário, solidário, motivado por prazer, herança, sagrado, laços pessoais na comunidade;

4. Entre legitimação e competência de dançar, cantar, encenar, rezar, 'brincar', enquanto membro de uma comunidade e a atitude e desejo, tida como invasiva de pessoas 'de fora', que interagem, dialogam, pesquisam, curtem, dançam, tocam, se identificam, aprendem e buscam se integrar de alguma maneira;

5. Entre a preservação e estudo das culturas tradicionais com seus objetos, materiais, instrumentos e sonoridades mais próximas a natureza e memoria oral e a criatividade, curiosidade, possibilidades das tecnologias e sonoridades novas, urbanas, técnicas, digitais que abrem novas portas; 
Muito pouco se escreve sobre mudanças possíveis e caminhos interessantes, considerando o fato de que as audiências participativas, essenciais para a continuidade das tradições cênicomusicais, estão mudando, visto que a comunidade local e vizinha está cada vez mais ausente nos rituais e festejos tradicionais por questões sociológicas econômicas, religiosas, etc. A pressão das condições e ambientes em transformação, da cultura midiática, das novas tecnologias, das políticas locais, dos artistas, músicos e produtores culturais contribuem para o surgimento de conflitos e transformações maiores, sobre os quais pesquisadores e estudiosos culturais têm pouca influência. Por outro lado, esta realidade traz consigo novas possibilidades e soluções estéticas, culturais e performáticas. Observa-se que no campo das músicas populares urbanas, contextos específicos de produção cultural profissional são largamente aceitos e pouco questionados, como se fossem realidades totalmente distintas. $\mathrm{Na}$ verdade, as fronteiras, em muitos casos, são e sempre foram muito maleáveis e permissíveis, pela própria história e característica do surgimento das músicas populares, rurais e urbanas.

A divisão entre música tradicional e popular, no contexto africano é mais flexível, mesmo no espaço do debate político, porque é vivido nos respectivos países como uma espécie de continuidade, diferente da diáspora africana, onde as tradições musicais geralmente ocupam um lugar de resistência e preservação da tradição oral, às vezes em lugares e populações geograficamente delimitados. Os grandes músicos africanos de carreira internacional têm-se defendido contra os preconceitos e críticas constantes, sobre a perda da originalidade e característica das músicas africanas, sem levar em conta, as grandes transformações socioculturais, políticos e econômicas nos demais países africanos. Os artistas alegam seu direito legítimo de fazer escolhas e desenvolver gostos estéticos diferenciados como qualquer cidadão euro-americano nos ditos países desenvolvidos, assim se libertando do peso e da cobrança colonial, literalmente descolonizando as mentes e criações musicais, sem ranço:

Assim jovens músicos da África ocidental, depois do período da síndrome „Copyright“, começaram a experimentar com vários estilos Afro-Pop. Ao mesmo tempo aconteceu uma revitalização da música tradicional de guitarra e essas duas correntes de música pop e música popular neo-tradicional começaram a se aproximar e se influenciar mutuamente. A situação hoje é muito diferente da dos dias, quando surgiu a música highlife. Naquele tempo reinava o colonialismo, quando os músicos africanos copiaram música ocidental (no entanto, maior repertório era a música negra americana). Hoje a África ocidental é independente, a música tradicional assumiu seu lugar devido e reconhecido e a música ocidental que eventualmente é absorvida, geralmente é a música afro-americana que hoje 
busca a se orientar em direção a África, para obter suas inspirações. Este fato tem tido um efeito libertador sobre a mentalidade colonial, a qual fez sofrer muitos músicos africanos, ou seja, para copiar e tocar o estilo ocidental contemporâneo, precisa conhecer e pesquisar as raízes africanas dessas músicas. As coisas percorreram um circuito completo e uma nova atitude se instalou na cena musical da África ocidental, que abre o potencial criativo imenso de suas músicas e quando isso acontecer, terá repercussão muito além do seu continente. (COLLINS, 1991, p. 31)

No Brasil, na crítica acadêmica, ainda há pouco lugar para o debate do músico popular da tradição oral que poderia ser visto e reconhecido como artista e pessoa criativa, interessado em dialogar com outros músicos, artistas, grupos e audiências, compostas por apreciadores, consumidores das artes e músicas populares em eventos e espaços, que promovem as tradições cênico-musicais. Do mesmo modo, pouco se leva em conta a possibilidade e importância de provocar no artista popular uma reflexão sobre seu fazer musical e artístico, sua concepção e performance estética (instrumentos, timbres, repertórios, improvisação, arranjos coreográficos e musicais, utilização de espaços, indumentária, vestimenta). Tampouco se reconhece a via dupla das expressões estéticas das culturas populares, no sentido da visibilidade e do consumo cultural, que pode, sim, interessar tanto aos artistas populares quanto aos possíveis consumidores ou participantes presentes em eventos tradicionais ou recriados (reinventados). É interessante observar, como na África ocidental, nos diversos estilos musicais populares, depois de um tempo de 'devoração' da cultura ou pela cultura ocidental, renasce o interesse pelas músicas tradicionais, muitas vezes em mesclas interessantes e novas roupagens.

Para finalizar a reflexão desse artigo, que seria na verdade um debate a ser continuado, ouvimos o famoso escritor, compositor e músico Francis Bebey que sugere um caminho de abertura e ampliação das possibilidades para a música africana, contribuindo com sua preservação e divulgação, mantendo seu lugar devido, e enfrentando sem medo, as influências de músicas e culturas ocidentais, recomendações estas, que poderiam ser pensadas e institucionalizadas também na cultura brasileira. (BEBEY, 1975, pp. 139-140). Entre os caminhos práticos pelos quais podemos alcançar a integração, gostaríamos de sugerir os objetivos seguintes:

- A organização de competições musicais e outros eventos culturais que poderiam ser lugares de encontro entre músicos tradicionais e modernos.

- A criação de companhias folclóricas que apresentam as artes tradicionais com ênfase especial na música.

- A formação de orquestras tradicionais que iriam receber assistência financeiro para que fiquem capacitados para manter o contato próximo com 
as formas artísticas ancestrais e preservar a pureza das expressões.

- O pagamento de todos os músicos que iriam gravar para a rádio e em LP

- A promoção de músicas tradicionais pelas companhias fonográficas na mesma escala que seriam gravadas as músicas populares para comercializar.

- A consolidação de centros subsidiados de pesquisa etnomusicológica, centros africanos de construção de instrumentos e conservatórios de música africana.

- A emissão das músicas africanas pelas estações de rádio, por todo continente, iria ajudar a familiarizar uns aos outros com suas músicas.

\section{Referências Bibliográficas}

BEBEY, Francis. African Music. A people's art. New York, Laurence Hill Books, 1975.

BENDER, Wolfgang. Sweet Mother: Afrikanische Musik. Wuppertal: Edtion Trickster im Peter Hammer Verlag, 2000.

BENGA, Ndiouga Adrien. L'air da la ville rend libre - musique urbaine e modernité Métisse - des groupes de musique des années 1950 aux posse des années 1990. Département d'Histoire, Université Cheikh Anta Diop, Dakar.

BROUGHTON, S. Ellington, M. Trillo, R. World Music Vol. 1. London: The Rough Guides, 1999.

COLLINS, John. Die populãre Musik in Westafrika nach dem Zweiten Weltkrieg. Em ERLMANN, Veit. Populãre Musik in Afrika. Berlin: Museum f. Völkerkunde, 1991, p.15-31.

DIOUF, Mamadou. The French Colonial Policy of Assimilation and the Civility of the Originaires of the four Comunes (Senegal), a Nineteenth Century Globalization Project. Em MEYER, Birgit e GESCHIERE, Peter. Globalization and Identity. Oxford: Blackwell, 1999.

GUILBAULT, Jocelyne. "Beyond the 'World Music' Label - Ethnography of Transnational Musical Practices.” Conference paper: Grounding Music, Berlin, 1996.

NKETIA, J. H. Kwabena. "Musik in afrikanischen Kulturen" em STOCKMANN, Erich (org.) Musikkulturen in Afrika. Berlin: Verlag Neue Musik, 1987.

PANZACCHI, Cornelia. Mbalax Mi. Musikszene Senegal. Wuppertal: Edition Trickster im Peter Hammer Verlag, 1997.

ROBERTS, John Storm. Black Music of two Worlds. African, Caribbean, Latin and AfricanAmerican Traditions. Belmont: Thomson-Schirmer, 1998.

SADIE, Stanley, ed. The New Groves Dictionary of Music and Musicians. 20 vols. Londres: Macmillan, 1980.

STOCKMANN, Erich (org.) Musikkulturen in Afrika. Berlin: Verlag Neue Musik, 1987.

\section{Recebido em 28/05/16 - Aprovado em 06/07/16}

